\title{
Production of disperse particles of CdS from thiourea solutions in the presence of amino acids
}

\author{
D.S.Sofronov, K.N.Belikov, E.M.Sofronova, \\ P.V.Matejchenko*, N.V.Babayevskaya*
}

\author{
Division of Chemistry of Functional Materials of STC "Institute for Single \\ Crystals", National Academy of Sciences of Ukraine, \\ 60 Lenin Ave., 61001 Kharkiv, Ukraine \\ "Institute for Single Crystals, STC "Institute for Single Crystals" National \\ Academy of Sciences of Ukraine, 60 Lenin Ave., 61001 Kharkiv, Ukraine
}

Received December 25, 2012

\begin{abstract}
Synthesis of fine-dispersed particles of CdS by precipitation from thiourea solutions in the presence of different amino acids is carried out. It is found that the presence of $\varepsilon$-aminocapronic, glutamic and $n$-aminobenzoic acids leads to the formation of small lamellar particles. Introduction of $n$-aminobenzoic acid in reaction mixture allows to increase a specific surface by 30 times.
\end{abstract}

Проведен синтез мелкодисперсных частиц CdS путем осаждения из раствора тиомочевины в присутствии аминокислот. Установлено, что в присутствии є-аминокапроновой, глутаминовой и $n$-аминобензойной кислот формируются мелкие пластинчатые частицы. Введение $n$-аминобензойной кислоты позволяет увеличить удельную поверхность в 30 раз.

\section{Introduction}

CdS nanoparticle based materials are of great interest for researchers due to potential possibility of their use in elements of solar batteries [1], optoelectronics [2], biological markers [3] and photochemistry [4]. Morphological characteristics have considerable impact on properties of nanoparticles. Therefore, a methodology of controlled synthesis of the particles with the predefined structure and morphology of a surface is of great practical interest.

There are several methods proposed for production of CdS nanoparticles: electrochemical [5], micellar [6], solvothermal [7], hydrothermal [8]. The simplest method of synthesis of cadmium sulfide particles is precipitation from water solutions by sulfonating reagent. As the reagent, thiourea
(TU) can be used. Despite seeming simplicity of precipitation of sulfides particles from thiourea solutions, process of particles formation will depend on many factors: temperature, duration of synthesis, concentration of components, etc.

During the initial period of CdS precipitation from $0.01-1 \mathrm{M} \mathrm{Cd}\left(\mathrm{NO}_{3}\right)_{2}$ solutions formation of citreous particles in the form of plates with the size from 50 to $100 \mathrm{~nm}$ [9] is observed. Increase in duration of synthesis (up to $20 \mathrm{~min}$ and more) results in merging of small plates in large agglomerates $(0.5-1 \mu \mathrm{m})$ of red color. The major factors influencing formation of CdS particles are the concentration of thiourea solution and sedimentation temperature. Decrease in the temperature to $20-25^{\circ} \mathrm{C}$ or increase in thiourea concentration above the stoichiometry leads to formation of spheri- 

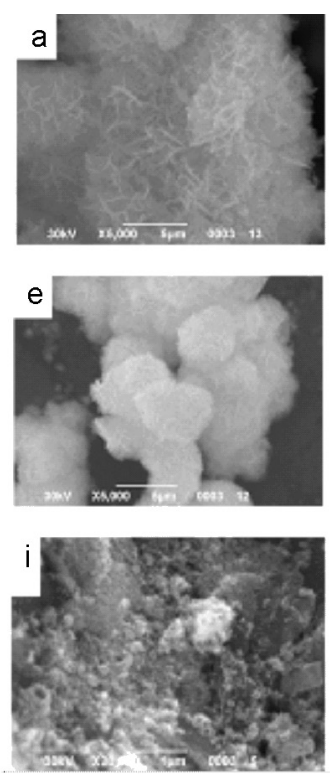

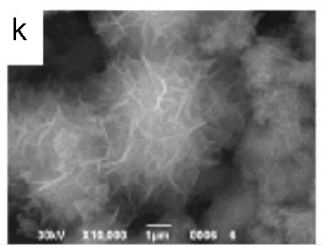

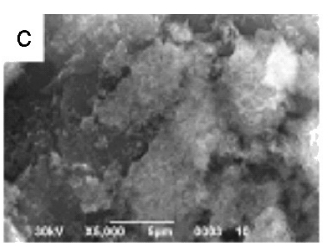
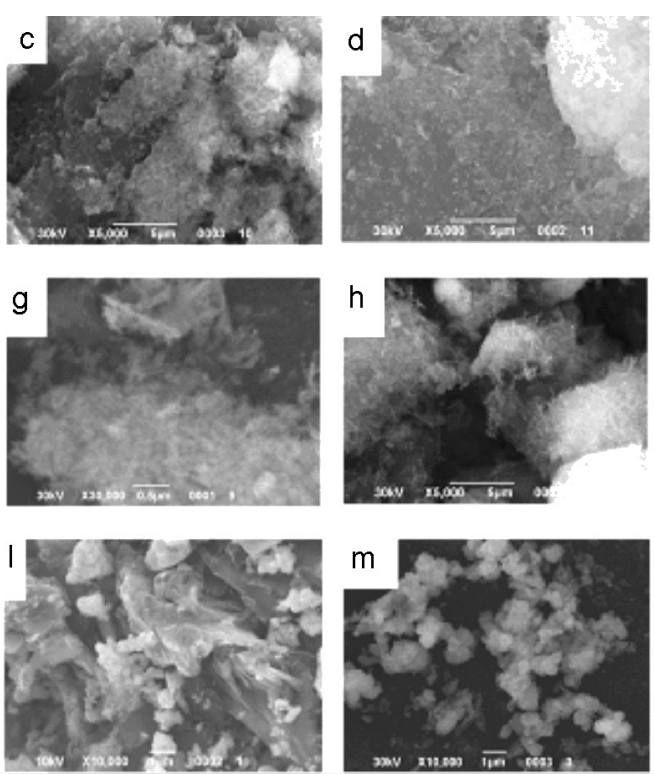

Fig. 1. SEM images of CdS particles synthesized at $20^{\circ} \mathrm{C}$ with the following alanine concentration and $C_{\mathrm{Cd}} / C_{\mathrm{TU}}$ ratio: a $-0.005 \mathrm{M}$ and $1: 1 ; \mathrm{b}-0.005 \mathrm{M}$ and $1: 4 ; \mathrm{c}-0.01 \mathrm{M}$ and $1: 1 ; \mathrm{d}-0.01 \mathrm{M}$ and $1: 2 ; \mathrm{e}-0.01 \mathrm{M}$ and $1: 4 ; \mathrm{f}-0.05 \mathrm{M}$ and $1: 1 ; \mathrm{g}-0.05 \mathrm{M}$ and $1: 4 ; \mathrm{h}-0.1 \mathrm{M}$ and $1: 1 ; \mathrm{i}-$ $0.1 \mathrm{M}$ and $1: 2 ; \mathrm{k}-0.1 \mathrm{M}$ and $1: 4 ; 1-0.5 \mathrm{M}$ and $1: 1 ; \mathrm{m}-0.5 \mathrm{M}$ and $1: 4$.

cal particles of two types: with the size of 300-500 $\mathrm{nm}$ and with the size of 4-6 $\mu \mathrm{m}$, consisting of plates with thickness of a wall of $50-80 \mathrm{~nm}$.

One of ways of control of morphological characteristics is introduction in the reaction mixture of various surfactants, in particular amines (ethylenediamine [10], oleylamine [11], triethanolamine [12]) and amino acids [13-15].

In the present work, we report the synthesis of fine-dispersed CdS particles from thiourea solutions in the presence of glycine, alanine, $\varepsilon$-aminocapronic, glutamic and $n$-aminobenzoic acids. Also, morphological characteristics of the obtained particles are investigated.

\section{Experimental}

All reagents used were analytical grade. Cadmium solution was prepared from $\mathrm{Cd}\left(\mathrm{NO}_{3}\right)_{2} \cdot 4 \mathrm{H}_{2} \mathrm{O}$ salt.

Precipitation of CdS was carried out as follows: $100 \mathrm{ml}$ of $0.1 \mathrm{M} \mathrm{Cd}\left(\mathrm{NO}_{3}\right)_{2}$ solution was poured in a round-bottomed flask of $250 \mathrm{ml}$ and water ammonia solution was added to $\mathrm{pH}$ 11.5-12. Then, thiourea solution in a molar ratio of $\mathrm{Cd}^{2+} / \mathrm{TU} 1: 1,1: 2$ or 1:4 was added at continuous stirring. At the last step amino acid was added so that its final concentration in solution varied within 0.005-0.5 M. The temperature of reaction mixtures during precipitation was 20 and $100^{\circ} \mathrm{C}$. Time of synthesis at the tem- perature of $100^{\circ} \mathrm{C}$ was $1 \mathrm{~h}$ and $12 \mathrm{~h}$ for precipitation at $20^{\circ} \mathrm{C}$. Upon termination of synthesis the received sediment was filtered, washed out several times distilled water and dried under vacuum at $60^{\circ} \mathrm{C}$ within $6 \mathrm{~h}$.

Powder X-ray analysis was performed on a powder diffractometer Siemens D500 $\left(\mathrm{CuK}_{\alpha}\right.$ with a graphite monochromator in the secondary beam). Full X-rays diffraction patters were measured within range $10<2 \theta<90^{\circ}$ with a step of 0.02 and the accumulation time of 10 seconds for each point. Study of the surface morphology of the powders obtained was carried out using a scanning microscope (SEM) JSM-6390LV. The $\mathrm{pH}$ value was measured by a $\mathrm{pH}$ meter pH-150 with a glass electrode and auxiliary silver chloride electrode.

Specific surface area of the powders obtained was measured by Brunauer-EmmettTeller (BET) method.

\section{Results and discussion}

Regardless of concentration of amino acids, formation of citreous and red powders was observed at 20 and $100^{\circ} \mathrm{C}$, respectively. According to XRD studies a citreous powder has a wurtzite structure with the following lattice parameters: $a=4.136 \AA$ and $c=6.713 \AA$. A red powder is a mixture consisting mainly from sphalerite modification with the lattice parameter $a=5.818 \AA$ and wurtzite modification with the lattice 

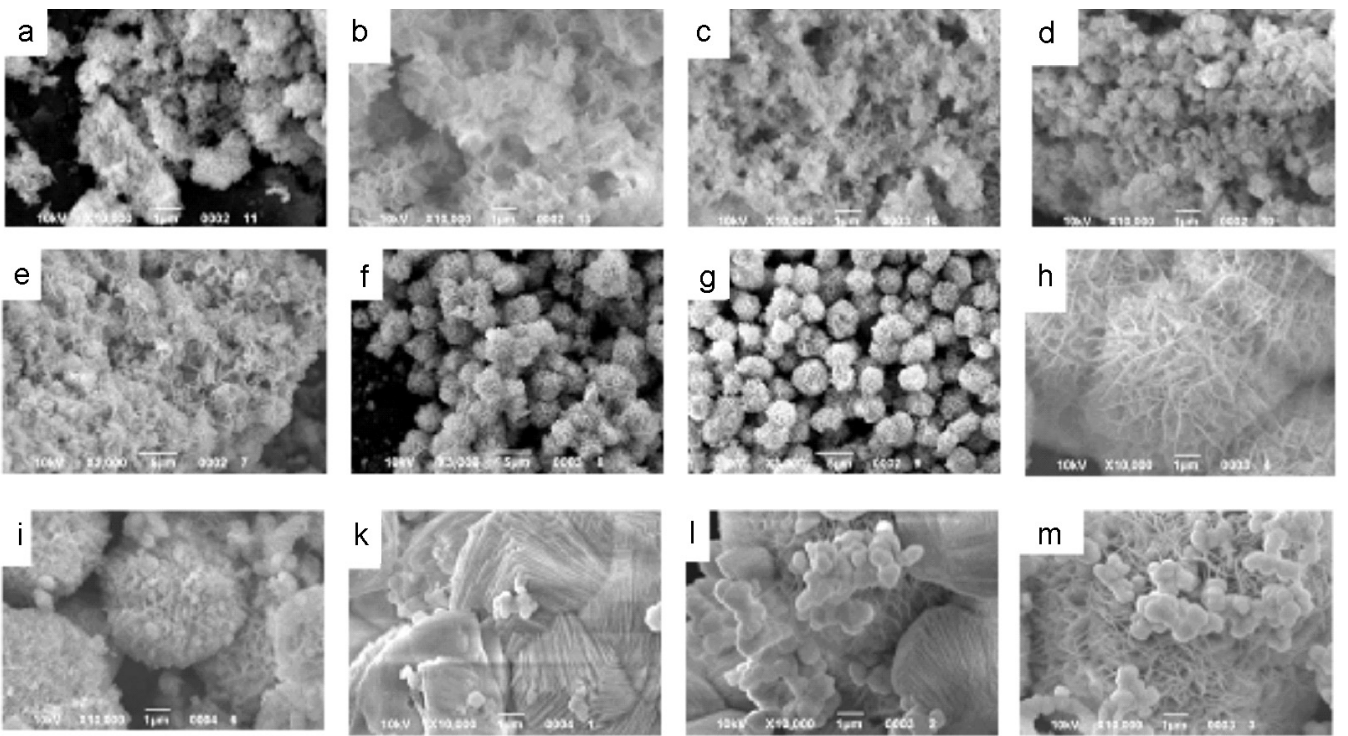

Fig. 2. SEM images of CdS particles synthesized at $100^{\circ} \mathrm{C}$ with the following alanine concentration and $C_{\mathrm{Cd}} / C_{\mathrm{TU}}$ ratio: a $-0.005 \mathrm{M}$ and $1: 1 ; \mathrm{b}-0.005 \mathrm{M}$ and $1: 4 ; \mathrm{c}-0.01 \mathrm{M}$ and $1: 1 ; \mathrm{d}-0.01 \mathrm{M}$ and $1: 2 ; \mathrm{e}-0.01 \mathrm{M}$ and $1: 1 ; \mathrm{f}-0.05 \mathrm{M}$ and $1: 2 ; \mathrm{g}-0.05 \mathrm{M}$ and $1: 4 ; \mathrm{h}-0.1 \mathrm{M}$ and $1: 1 ; \mathrm{i}-$ $0.1 \mathrm{M}$ and $1: 4 ; \mathrm{k}-0.1 \mathrm{M}$ and $1: 1 ; 1-0.5 \mathrm{M}$ and $1: 2 ; \mathrm{m}-0.5 \mathrm{M}$ and $1: 4$.

parameters $a=4.136 \AA$ and $c=6.713 \AA$. Abundance of wurtzite modification was not greater than $10 \mathrm{wt}$. \%. The obtained data is in a good agreement with the results published before [9]. Powders with wurtzite modification were precipitated only at short heating, and more continious synthesis led to formation of mixes of wurtzite and sphalerite modifications.

\subsection{Effect of glycine and alanine}

SEM images of CdS particles obtained in the presence of alanine are shown in Fig. 1-2. Addition of $0.005 \mathrm{M}$ of alanine (Fig. 1 ,a) results in formation of flower-like particles, which size is getting smaller with increase in thiourea concentration. For example, when $C_{\mathrm{Cd}} / C_{\mathrm{TU}}$ ratio is $1: 1$ the size of agglomerates is more than $5 \mu \mathrm{m}$ (Fig. 1,a), and when $C_{\mathrm{Cd}} / C_{\mathrm{TU}}$ ratio is $1: 4$ the size of agglomerates is $2-3 \mu \mathrm{m}$ (Fig. $1, \mathrm{~b}$ ). The subsequent increase in alanine concentration up to $0.1 \mathrm{M}$ (Fig. 1,c-k) leads to destruction of flowers and formation of the shapeless agglomerated sediments consisting of plates. When the concentration of alanine is $0.5 \mathrm{M}$, compact shapeless layered sediments (Fig. $1,1)$ are formed. Increase in thiourea concentration to the ratio $C_{\mathrm{Cd}} / C_{\mathrm{TU}}$ of $1: 4$ leads to formation of spherical particles (Fig. 1,m). Another factor having impact on formation of particles is the temperature of precipitation. At $C_{\mathrm{Cd}} / C_{\mathrm{TU}}$ ratio of $1: 1,0.005 \mathrm{M}$ of alanine and the temperature of sedimenta- tion of $100^{\circ} \mathrm{C}$ (Fig. 2, a) the fine-disperse precipitation consisting of spherical particles is formed. Flowers are getting more condensed with increase in thiourea concentration (Fig. 2,b).

If concentration of alanine is higher than $0.01 \mathrm{M}$ formation of the shapeless agglomerates consisting of separate small plates (Fig. 2, c-d) is observed. Increase in alanine concentration up to $0.1 \mathrm{M}$ (Fig. 2,e-i) promotes formation of flower-like structures which size depends on $C_{\mathrm{Cd}} / C_{\mathrm{TU}}$ ratio. When concentration of alanine is $0.5 \mathrm{M}$ and $C_{\mathrm{Cd}} / C_{\mathrm{TU}}$ ratio is $1: 1$, large layered agglomerates are formed, and when $C_{\mathrm{Cd}} / C_{\mathrm{TU}}$ ratio is $1: 4$ the transition from layered to flowerlike structures is observed.

In case of precipitation of CdS particles at $20^{\circ} \mathrm{C}$ in the presence of glycine (0.005:0.01 M), irrespective of the thiourea contents large spherical particles with the size of $5 \mu \mathrm{m}$ in the form of a flower are formed. When concentration of glycine is higher than 0.1 M it promotes formation of dense large shapeless particles. The higher thiourea concentration, the larger size of CdS particles were obtained. Carrying out precipitation at $100^{\circ} \mathrm{C}(0.005-0.01 \mathrm{M}$ of glycine) leads to formation of spherical particles with size about $1 \mu \mathrm{m}$. Increase in glycine concentration above $0.01 \mathrm{M}$ results in formation of flower-like particles with the size of 2-4 $\mu \mathrm{m}$, irrespective of thiourea concentration. 

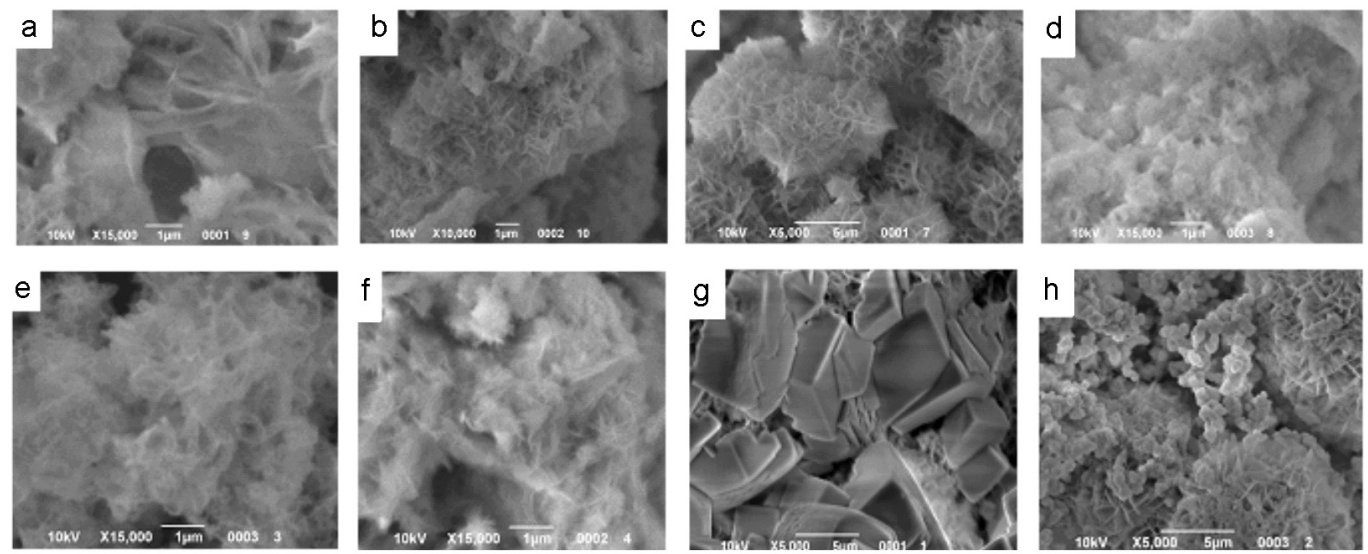

Fig. 3. SEM images of CdS particles synthesized at $20^{\circ} \mathrm{C}$ with the following aminocapronic acid concentration and $C_{\mathrm{Cd}} / C_{\mathrm{TU}}$ ratio: a $-0.005 \mathrm{M}$ and $1: 1 ; \mathrm{b}-0.005 \mathrm{M}$ and $1: 4 ; \mathrm{c}-0.01 \mathrm{M}$ and $1: 1$; $\mathrm{d}-0.01 \mathrm{M}$ and $1: 4 ; \mathrm{e}-0.1 \mathrm{M}$ and $1: 1 ; \mathrm{f}-0.1 \mathrm{M}$ and $1: 4 ; \mathrm{g}-0.5 \mathrm{M}$ and $1: 1 ; \mathrm{h}-0.5 \mathrm{M}$ and 1:4.

\subsection{Effect of E-aminocapronic acid}

SEM images of CdS particles synthesized in the presence of $\varepsilon$-aminocapronic acid are shown in Fig. 3. When synthesis is carried out at $20^{\circ} \mathrm{C}$ in the presence of $0.005-0.1 \mathrm{M}$ of $\varepsilon$-aminocapronic acid agglomerated friable sediments are formed (Fig. 3,a-f).

Increase in $\varepsilon$-aminocapronic acid concentration up to $0.5 \mathrm{M}$ at $C_{\mathrm{Cd}} / C_{\mathrm{TU}}$ ratio of $1: 1$ leads to formation of large particles in the form of blocks with the size of a few $\mu \mathrm{m}$ (Fig. 3,g). When the ratio $C_{\mathrm{Cd}} / C_{\mathrm{TU}}$ is $1: 4$ spherical particles of two types (Fig. 3,h) are produced: small ones with the size of 0.5-1 $\mu \mathrm{m}$ and flower-like particles with the size about $10 \mu \mathrm{m}$. When synthesis is carried out at $100^{\circ} \mathrm{C}$ in the presence of $0.005-$ $0.1 \mathrm{M}$ of $\varepsilon$-aminocapronic acid formation of mainly spherical flower-like particles with the size of $5-10 \mu \mathrm{m}$ is observed.

\subsection{Effect of glutamic and n-aminobenzoic acids}

Glutamic acid in the range of concentration of 0.005-0.5 M irrespective of the thiourea contents promotes formation of very thin plates which have been chaotically bound among themselves (Fig. 4). The increase in temperature of synthesis to $100^{\circ} \mathrm{C}$ didn't lead to essential change of morphology of particles. Addition of $0.005 \mathrm{M}$ of $n$-aminobenzoic acid has similar impact on formation of particles. Irrespective of temperature of precipitation and $C_{\mathrm{Cd}} / C_{\mathrm{TU}}$ ratio in the presence of $n$-aminobenzoic acid formation of the thin plates which have been chaotically bound among themselves is observed.
For the purpose of determination of a specific surface area the samples synthesized without and with an addition of amino acids were selected. According to the obtained experimental data CdS powder synthesized by precipitation from thiourea solution without an amino acid addition at a ratio of $C_{\mathrm{Cd}} / C_{\mathrm{TU}} 1: 4$ has the specific surface area of $1.5 \mathrm{~m}^{2} / \mathrm{g}$. The samples of CdS obtained in the presence of $0.01 \mathrm{M}$ of glycine, alanine and $\varepsilon$-aminocapronic at a ratio of $C_{\mathrm{Cd}} / C_{\mathrm{TU}} 1: 4$ ratio have the specific surface area of $2.5,2.6$ and $8.2 \mathrm{~m}^{2} / \mathrm{g}$, respectively. The powder obtained in the presence of $0.005 \mathrm{M}$ of glutamic and $n$-aminobenzoic acids at a ratio of $C_{\mathrm{Cd}} / C_{\mathrm{TU}} 1: 4$ have the specific surface area of 20 and $44 \mathrm{~m}^{2} / \mathrm{g}$, respectively. Thus, introduction of $n$-aminobenzoic acid in the reaction mixture allows to increase a specific surface area by 30 times.

\section{Conclusions}

CdS precipitation from thiourea solutions in the presence of glycine, alanine, $\varepsilon$-aminocapronic, glutamic and $n$-aminobenzoic acids is carried out, and morphological characteristics of particles are studied. In the presence of glycine and alanine flowerlike structures which size depends on precipitation temperature and thiourea concentration are mainly formed. Introduction in a reaction mixture $\varepsilon$-aminocapronic, glutamic and $n$-aminobenzoic acids irrespective of precipitation temperature and thiourea concentration promotes formation of very thin plates which have been chaotically bound among themselves. It is found that introduction of $n$-aminobenzoic acid in the reac- 

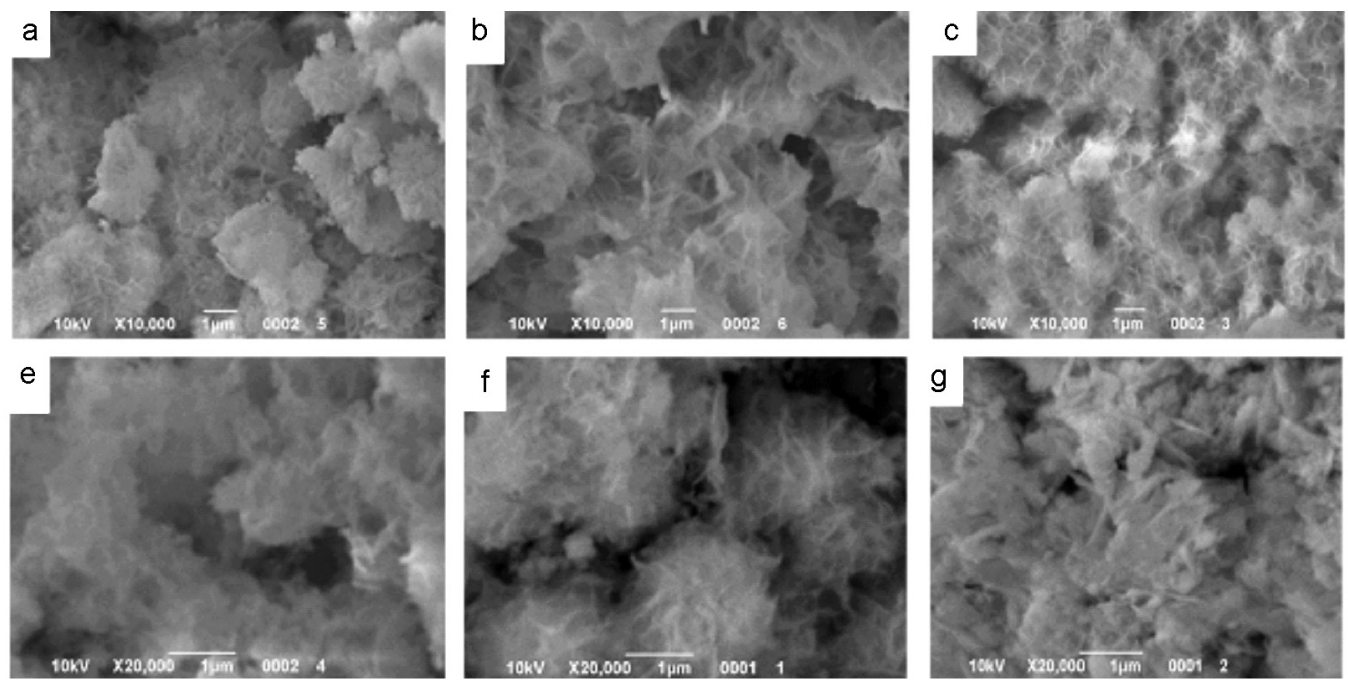

Fig. 4. SEM images of CdS particles synthesized at $20^{\circ} \mathrm{C}$ with the following glutamic acid concentration and $C_{\mathrm{Cd}} / C_{\mathrm{TU}}$ ratio: a $-0.005 \mathrm{M}$ and $1: 1 ; \mathrm{b}-0.005 \mathrm{M}$ and $1: 4 ; \mathrm{c}-0.01 \mathrm{M}$ and $1: 1 ; \mathrm{d}-$ $0.01 \mathrm{M}$ and $1: 4$; e - 0.5 $\mathrm{M}$ and $1: 1 ; \mathrm{f}-0.5 \mathrm{M}$ and $1: 4$.

tion mixture allows to increase a specific surface area by 30 times.

\section{References}

1. X.Zhang, Y.Xie, Q.Zhao, Y.Tian, New J. Chem., 27, 827 (2003).

2. R.Agarwal, C.Barrelet, Ch.Lieber, Nano Lett., 5, 917 (2005).

3. K.-T.Yong, J.Qian, I.Roy et al., Nano Lett., 7, 761 (2007).

4. L.Sheeney-Haj-Ichia, B.Basnar, I.Willner, Angew. Chem. Int. Ed., 44, 78 (2005).

5. D.Routkevitch, T.Bigioni, M.Moskovits, J.M.Xu, J.Phys. Chem., 100, 14037 (1996).

6. Y.Xiong, Y.Xie, J.Yang et al., J.Mater. Chem., 12, 3712 (2002).

7. D.Xu, Z.Liu, J.Liang, Y.Qian, J.Phys.Chem. $B, 109,14344$ (2003).
8. Y.Li, Y.Hu, S.Peng et al., J.Phys.Chem.C, 113, 9352 (2009).

9. D.Sofronov, E.Sofronova, V.Baumer et al., Functional Materials, 18, 523 (2011).

10. J.Yao, G.Zhao, D.Wang, G.Han, Mater. Lett., 59, 3652 (2005).

11. B.Geng, J.Ma, F.Zhan, Mater. Chem. and Phys., 113, 534 (2009).

12. D.Kim, Ki-Deuk Min, J.Lee et al., Mater. Sci. and Engin. B, 131, 13 (2006).

13. M.Wang, L.Sun, X.Fu et al., Solid State Commun., 115, 493 (2000).

14. A.Rakovich, V.Stockhausen, A.Susha et al., Colloids and Surfaces A: Physicochem. and Engin. Aspects, 317, 737 (2008).

15. W.Qiu, M.Xu, X.Yang et al., J. Alloys and Compounds, 509, 8413 (2011).

\section{Отримання дисперсних частинок CdS з тіосечових розчинів у присутності амінокислот}

\section{Д.С.Софронов, К.М.Беліков, О.М.Софронова, П.В.Матейченко, Н.В.Бабаєвська}

Розглянуто вплив гліцину, аланіну, $\varepsilon$-амінокапронової, глутамінової та $n$-амінобензойної кислот на морфологічні властивості сульфіду кадмію при осадженні з тіосечових розчинів. Встановлено, що найбільший вплив на формування роблять $\varepsilon$-амінокапронова, глутамінова і $n$-амінобензойна кислоти. Їх присутність сприяє формуванню дрібних пластинок. Показано, що введення $n$-амінобензойної кислоти дозволяє збільшити питому поверхню у 30 разів. 